\title{
Earnings management in global background
}

\author{
Lenka Strakova ${ }^{1 *}$ \\ University of Zilina, Faculty of Operation and Economics of Transport and Communications, \\ Department of Economics, Univerzitna 1, 01026 Zilina, Slovakia
}

\begin{abstract}
Earnings management is a general term in accounting decisions that may affect the results of the financial statements. Financial statements represent the core of information is used not only by internal but also external entities. Their role is to provide a true picture of the financial situation and the performance of a particular business in an international environment. In practice, however, there may be opportunities to influence accounting information using a variety of methods and techniques, and as a result, the financial statements lose their function and misrepresent the accounting data, resulting in profit manipulation. Profit manipulation is also dealt with by the phenomenon of earnings management, which is a topical topic in the world of finance in the international environment. This is a very complex and multifaceted phenomenon occurring in companies, irrespective of their territory, area of business or size. Several profit models are used to measure and detect earnings management, whose detection capability varies. This paper focuses on the selection of profit models according to individual forms of earnings management and the assessment of variable profit models in the V4 countries.
\end{abstract}

\section{Introduction}

Each of the companies sets specific goals within their business activities, which they try to achieve during their operation. One of these goals is to make a profit. Profit is the most important item in the financial statements. Financial statements represent the core of information that is used not only by internal but also external entities. Their role is to present a true and fair view of the financial situation and performance of a particular business. One of the authors dealing with this issue is by the opinion that profitable platforms bring many economic benefits.[1] In practice, however, there may be opportunities to influence the accounting information through the use of different methods and techniques, and as a result, the financial statements lose their function and misrepresent the accounting data and manipulate the profit. Throught the making financial decisions, managers choose from the possible alternatives that will maximize the expected profits for businesses.[2] The earnings management phenomenon also deals with profit manipulation. Earnings management is an increasingly topical subject and therefore it is essential for both internal and external users of financial statements to understand the importance of earnings management. Experts in the field have different views and opinions about earnings management. Some of them consider this phenomenon to be a legal way of managing profits, while others consider it to be illegal manipulation of profits. For this reason, many

\footnotetext{
*Corresponding author: lenka.strakova@fpedas.uniza.sk
} 
scientific studies or professional methods and techniques have been developed and are based on the measurement and detection of earnings management. There are a large number of models for measuring and detecting earnings management, the essence of which is a discretionary accrual. The individual models differ in their nature in that they do not distinguish between total and discretionary, and some models in turn distinguish between discretionary and non-discretionary. Each model is formed under specific conditions of the country, considering the development of its capital market, economic and financial situations and potential financial risks. That is the reason why the models are not applicable in every economy.[3]

\subsection{Definition of earnings management}

Earnings management is a complex and multifaceted phenomenon occurring in businesses regardless of their area of business, business or size. The literature contains definitions of earnings management according to several authors:

Table1. Definitions of earnings management.

\begin{tabular}{|l|l|l|}
\hline White & Black & Grey \\
\hline $\begin{array}{l}\text { Ronen a Sadan (1981) } \\
\text { Demski(1998) }\end{array}$ & $\begin{array}{l}\text { Schipper (1989) } \\
\text { Levitt (1998) }\end{array}$ & $\begin{array}{l}\text { Fields, Lys a Vincent } \\
\text { (2001) } \\
\text { Scott (2003) }\end{array}$ \\
\hline \multicolumn{2}{|c|}{ Definition of earnings management } \\
\hline $\begin{array}{l}\text { Accounting method, which } \\
\text { depends on the level of } \\
\text { flexibility, helping to indicate } \\
\text { private information about the } \\
\text { future cash flow of the } \\
\text { company. }\end{array}$ & $\begin{array}{l}\text { Apply various techniques to } \\
\text { distort and reduce the } \\
\text { transparency of the company's } \\
\text { financial statements. }\end{array}$ & $\begin{array}{l}\text { Choice of opportunistic or } \\
\text { economically effective } \\
\text { billing method. }\end{array}$ \\
\hline
\end{tabular}

Another author defines earnings management as the sum of managerial decisions that do not result in reporting actual value-maximizing short-term income." It can be favorable, unfavorable and neutral. Positive EM reflects long-term value, unfavorable seeks to conceal short-term or long-term value, and neutral earnings management reflects true short-term performance.[4] Rezaee, in his studies, refers to earnings management as "frauds in financial statements representing intentional attempts by a business to deceive or deceive external users of published financial statements, in particular investors and creditors, by preparing and distributing materially incorrectly recorded financial statements".[5] The author McKee has a different view of earnings management, who thinks it is more of a purposeful and legal decision-making and reporting management with a view to achieving stable and predictable results.[6] Earnings management in an international environment is also defined as a strategic way to exercise discretion in managerial decision-making to influence profits that have been reported to external users or as a conscious intervention in the external financial reporting process for personal benefit.[7] Earnings management occurs when managers use judgment in financial reporting and in structuring transactions to alter financial statements because of misleading some partners with respect to the economic performance of the company. It represents the selection of accounting policies made by the manager in terms of revenue as well as the achievement of specific reported profit objectives. Earnings management involves artificially increasing or decreasing sales, profits or returns through aggressive accounting tactics. 


\subsection{The forms of earnings management}

There are two forms of profit management. The first form that managers use to manipulate their earnings is through real earnings management, that is, through the economic profit management that managers apply when deciding on the operating activities of an enterprise. The idea of economicprofit is based on the existence of opportunity costs that are very well known in the economic theory.[8] Managers are aware that by using economic profit management tactics they have to accept some loss of future cash flow in order to achieve the required short-term ratios. Other authors agree with the idea that in order for an enterprise to improve its financial performance, it is necessary for business managers to be fully informed about all aspects of financial performance and the costs involved.[9] Economic profit management is more difficult to detect because it involves investment and operational decision-making strategies that ultimately affect the company's cash flow. The second form of earnings management is called accrual-based earnings management and in translation means accounting profit management. Accounting profit management is based on accruals, which are designed to present the true performance of the business by capturing revenue and expenses in the period in which they were incurred.[10]

Table 2. Basic differences between REM profit management and ABM.

\begin{tabular}{|l|l|l|}
\hline & Realearnings management & Accrual-based management \\
\hline Implementation via & Operational decisions & Accounting principles \\
\hline Exploitation impact on & Operational activities & Financial statements \\
\hline $\begin{array}{l}\text { Direct/indirect impact } \\
\text { cash flow }\end{array}$ & Indirect impact \\
\hline
\end{tabular}

\subsection{Measurement and detection of earnings management}

The basis for measuring and detecting earnings management is an accrual based on the definition of the accrual principle. Accrual is one of the tools for investors or other external entities using information about the performance of individual companies. Based on the accrual principle, it is possible to record revenue at the time of product sale regardless of the time of cash receipt. Similarly, the costs associated with the revenue can be recognized in the period regardless of the time spent in cash. Accruals arise as a result of a timing mismatch between cash flows and the accounting treatment of transactions.

\subsection{Earnings models}

In the international environment, the evolution of EM detecting models begins with simple NDA abstracted models and continues to more sophisticated alternative models that attempt to decompose the overall accrual into discretionary and non-discretionary. However, the decomposition of the overall accrual is very demanding and there is no systematic evidence of the relative strength of alternative models for EM detection.[11] Another author distinguishes three approaches in EM detection: simple accrual models focus on individual accounting items and are applicable especially in financial institutions, total accrual models - focus on multiple accounting items and decompose the total accrual into discretionary and non-discretionary, investigating discontinuities in profit distribution.[12] The problem is that DA and NDA are not directly detectable. The overall accrual models therefore aim to estimate the non-discretionary part. The DA is then calculated as the difference between total and non-sparking accrual.[13] Depending on the assumption of constant NDA we distinguish static models assuming constant NDA such as. Healy model, or DeAngel model and dynamic models, which under the influence of 
internal and external factors do not assume the constant NDA, such as. Jones model or modified Jones model.[14] The fact that the NDA is not constant is particularly important when examining EM in the context of the financial crisis, since the economic changes that businesses are facing during a crisis have a significant impact on the NDA.[15] Within EM measurement and detection on a global basis, profit models are divided according to whether they detect accounting or economic profit management, or a combination thereof. The following figure shows the breakdown of profitable models into individual groups:

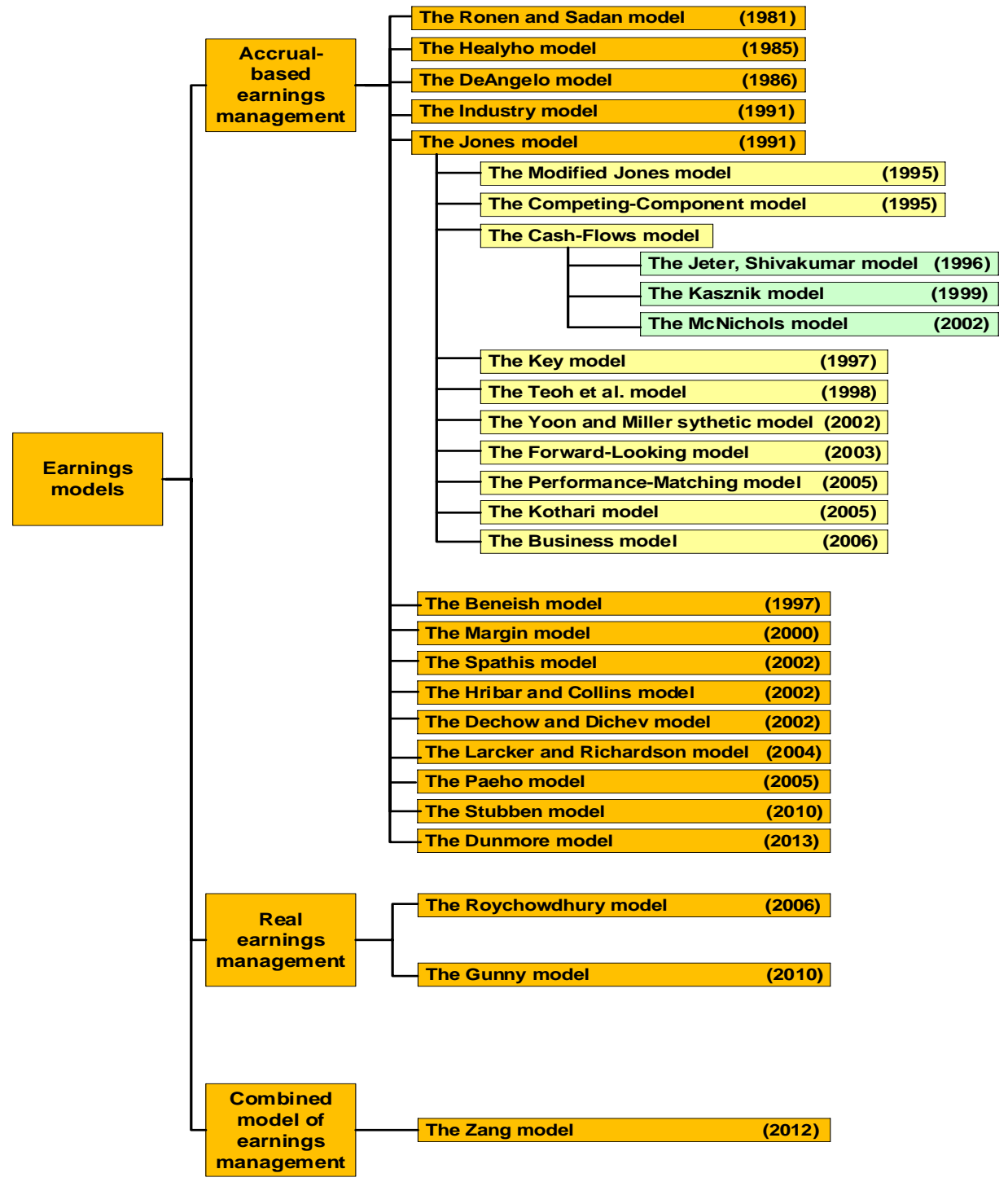

Fig. 1. Classification of profitable models.

\section{Methodology}

The description method and the method of classification of technical terms are used to specify the theoretical basis of earnings management. In the evaluation of individual profit 
models in the conditions of the V4 countries, a selection method is used, in which the profit models are selected according to their classification into individual types of earnings management and subsequently according to variables entering into individual profit models.

\section{Results and discussion}

The following chapter describes the selection of individual profit models related to the detection of earnings management in the V4 countries. The result of the selection of profit models is to find and identify the model most appropriate to the conditions of the V4 countries in terms of earnings management form and variables entering individual profit models. Different variables are entering different profit models, and it is necessary to identify those variables whose descriptive power reaches the highest level and at the same time it is necessary to estimate at least one of the given parameters. In selecting profitable models, the first step is to select models based on whether they focus on measuring and detecting accounting or economic profit management. Based on a graphical representation of the distribution of profit models presented in the profit models section, accrual-based earnings management models were selected on the basis of which the Roychowdhury model, Gunny model and Zang model were excluded from the range of models. The next step assesses the suitability of using profitable accounting models for profit management, and excludes the Healy model and the DeAngel model because both authors assume a nondiscretionary accrual consistency and, at the same time, immediately show the level of manipulation, resulting in is the impossibility of assessing their strength. The sectoral model was discarded due to a lack of knowledge of all the necessary values of the variables for individual sectors. The forward looking model was rejected due to unavailability of GR_sales, i.e. changes in revenue in year $t$ versus year $t+1$ divided by revenue in year $t$. In the case of the conflicting component model, a significant number of missing data on the cost of economic activity was observed. Performance-adjusted models have been excluded because of a mis-definition of the non-discretionary accrual as discretionary, resulting in extreme performance and a non-linear relationship between the accrual and the given performance. Furthermore, the models of authors Ronen and Sadan were excluded as they do not rank among the models of the overall accrual. In addition, models whose variables were not available were excluded in the analysis. We have eliminated the conflicting component model because of an undetectable variable, which is the cost of economic activity. We excluded the model by McNichols because of missing variables such as other assets, other liabilities and tax liabilities. We eliminated the synthetic model of Ye and Yoon and Miller based on missing variables such as normal non-monetary working capital and the cost of economic activity. We eliminated the Margin model due to a significant number of missing balance sheet items money and bank accounts, which made it impossible for us to calculate the NCWC variable, i. non-monetary working capital with which the synthetic model and the calculation of the WCA dependent variable, i.e. the working capital accrual applied by the Margin model, operate. The model of the author Beneish was discarded due to the missing fixed cost variable. We discarded the model of Larcker and Richardson because of the lack of market value. The Dunmore model was excluded because of the partition variable. We excluded the Stubben model due to a lack of revenue development for each quarter. 
Table 3. Overview of profitable models.

\begin{tabular}{|c|c|c|}
\hline Number & Excluded models & Model selection decision \\
\hline 1 & Model Ronena a Sadana & $\mathrm{x}$ \\
\hline 2 & Healyho model & $\mathrm{x}$ \\
\hline 3 & DeAngelovej model & $\mathrm{x}$ \\
\hline 4 & Odvetvový model & $\mathrm{x}$ \\
\hline 5 & Jonesovej model & $\checkmark$ \\
\hline 6 & Modifikovaný Jonesovej model & $\checkmark$ \\
\hline 7 & Model s výhl'adom do budúcnosti & $\mathrm{x}$ \\
\hline 8 & Model protichodných komponentov & $\mathrm{x}$ \\
\hline 9 & Jeter a Shivakumar model & $\checkmark$ \\
\hline 10 & McNichols model & $\mathrm{x}$ \\
\hline 11 & Kasznik model & $\checkmark$ \\
\hline 12 & Key model & $\checkmark$ \\
\hline 13 & Teoh, Welch a Wong model & $\checkmark$ \\
\hline 14 & Kothari model & $\checkmark$ \\
\hline 15 & Ye model & $\mathrm{x}$ \\
\hline 16 & Yoon a Miller model & $\mathrm{x}$ \\
\hline 17 & Margin model & $\mathrm{x}$ \\
\hline 18 & Beneishov model & $\mathrm{x}$ \\
\hline 19 & Paeho model & $\mathrm{x}$ \\
\hline 20 & Gunnyho model & $\mathrm{x}$ \\
\hline 21 & Larcker a Richardson model & $\mathrm{x}$ \\
\hline 22 & Dunmore model & $\mathrm{x}$ \\
\hline 23 & Roychodwdhuryho model & $\mathrm{x}$ \\
\hline 24 & Zangov model & $\mathrm{x}$ \\
\hline 25 & Spathis model & $\mathrm{x}$ \\
\hline 26 & Dechow a Dichev model & $\mathrm{x}$ \\
\hline 27 & Modely prispôsobené výkonnosti & $\mathrm{x}$ \\
\hline 28 & Stubben model & $\mathrm{x}$ \\
\hline 29 & Hribar a Collins model & $\mathrm{x}$ \\
\hline
\end{tabular}

From the total of twenty-nine profitable models, twenty-two models were excluded for the reasons mentioned above. The selection of profitable models resulted in the identification and identification of the most suitable models in the V4 countries according to the form of earnings management and variables of individual profit models. These profit models include Jones model that takes into account the impact of changes in the economic situation in the enterprise relative to the NDA, using independent variables, such as tangible fixed assets and sales, expressing their linear regression. According to this model, the time series of profits of individual enterprises is divided into two subperiods. Estimation period represents the first stage when the DA value is zero. Jones model expresses the relationship between the short-term accrual, the so-called. working capital accrual and change in sales, or the relationship between depreciation and long-term assets. Using regression, it is possible to estimate the necessary coefficients $\alpha 0^{\prime}, \alpha 1^{\prime}, \alpha 2^{\prime}$. Consequently, estimates of these coefficients can be implemented in the second stage formula, which is the "event period" when DA is not zero, which implies the existence of earnings management. Jones points to several assumptions of the model. The first assumption is that within the "estimation period" individual companies do not implement earnings management, as the 
assumption points to its biased measurement. The second assumption considers that the coefficients do not change over time, which may have an impact on the selection of the set of individual companies. The third assumption is based on non-discretionary revenue and suggests that if revenue is managed by discretionary revenue, some of the profit may be removed from the estimate of the discretionary accrual. A type I error assumes the detection of earnings management, although it does not occur, by an II error. The kind is not revealing earnings management in case of its occurrence.[16] Modified Jones model consists in adjusting the changes in sales due to the change in receivables. It was the reduction of the errors of DA measurements created in relation to the revenues that led the authors to modify this model. A prerequisite for the model is any induced change in sales revenue when the supplier credit is granted is considered as a result of earnings management, but other authors believe that it is not realistic for any induced changes in claims to be associated with the application of earnings management.[17] Another of the authors, Jeter and Shivakumar, modified the original Jones model in which, as a nondiscretionary part of earnings management, they defined cash flow from operating activities as a result of trying to improve Jones's model to measure EM in businesses with extremely reported cash flow.[18] The author of Kothari modified the Jones model in two ways. The first approach uses the least squares method to estimate DA, resulting in the matching of similar undertakings, while the second approach takes into account the return on assets to regulate the performance of the undertaking. Kasznik applied a cash flow change to the Jones model.[19] Teoh, Welch and Wong adjusted the Jones model using the short-term accrual, which they expressed as the difference between the change in non-cash short-term assets and the change in short-term operating liabilities, thus identifying the nondiscretionary part of the short-term accrual through business growth. Key model modified the Jones model by using intangible assets, assuming a relationship between depreciation and intangible assets.[20]

\section{CONCLUSION}

In the earnings management study in the V4 countries, there were limitations affecting the selection of profit models, which consisted of the missing variables contained in some profit models. Despite these limitations and based on the results presented in the capitol results and discussion, the objective of the study was met.

\section{Acknowledgements}

This research was financially supported by the Slovak Research and Development Agency - Grant NO. APVV-15-0505 Integrated model of management support for building and managing the brand value in the specific conditions of the Slovak Republic and VEGA $1 / 0428 / 17$ Creation of new paradigms of operational management at the threshold of the 21 st century in conditions of the Slovak republic, which authors gratefully acknowledge.

\section{References}

1. G.H. Poposcu, Participation in the Sharing Economy: Labor, Exchange, and Consumption. An Empirical Analysis. Journal of Self-Governance and Management Economics 6, 122-127 (2018)

2. K. Valaskova, V. Bartosova, P. Kubala, Behavioural Aspects of the Financial Decision-Making. Organizacija 52, 22-32 (2019) 
3. K. Valaskova, T. Kliestik, M. Kovacova, Management of financial risks in Slovak enterprises using regression analysis. Oeconomia Copernicana 9, 105-121 (2018)

4. J. Francis, K. Schipper, Earnings Management. Emerging Insights in Theory, Practice and Research. The Accounting Review 86, 2193-2196 (2011)

5. Z. Rezaee, Causes, consequences, and deterrence of financial statement fraud. Critical Perspectives on Accounting 16, 277-298 (2005)

6. K.B.N. Mikhaiel, New Perspective of Earnings Management: The Effect of Outsiders' Requirements on Managerial Choice of Earnings Management Mechanisms. American Research Institute for Policy Development 4, 58-77 (2015)

7. A. Marai, V. Pavlović, Earnings management vs financial reporting fraud - key features for distinguishing. ECONIS - Online Catalogue of the ZBW 10, 39-47 (2013)

8. J. Salaga, V. Bartosova, E. Kicova, Economic Value Added as a measurement tool of financial performance. Procedia Economics and Finance 26, 484-489 (2015)

9. F. Csaba, E. Neubbauer, H. MANSUR, A. TANGL, J. OLAH, J. POPP, The main transition management issues and the effects of environmental accounting on financial performance - with focus on cement industry. Administratie si Management Public 31, 52-66 (2018)

10. S.P. Kothari, N. Mizik, S. Roychowdhury, Managing for the moment: The role of Earnings management via real activities versus accruals in SEO valuation. The Accounting Review 91, 559-586 (2016)

11. P.M. Dechow, A.P. Hutton, J.H. Kim, R.G. Sloan, Detecting earnings management: A new approach. Journal of Accounting Research 50, 275-291 (2012)

12. M. Mcnichols, The Quality of Accruals and Earnings: The Role of Accrual Estimation Errors: Discussion. The Accounting Review. 77, 61-69 (2002)

13. H. Hoglund, Detecting earnings management with neural networks. Expert Systems with Applications 39, 9564-9570 (2012)

14. P.M. Dechow, R.G. Sloan, A.P. Sweeney, Detecting earnings management. American Accounting Association: The Accounting, Review 70, 193-225 (1995)

15. R.S. Kaplan, Comments on Paul Healy. Journal of Accounting and Economics. 7, 109113 (1985)

16. J.J. Jones, Earnings management during import relief investigation. Journal of Accounting Research 29, 193-228 (1991)

17. S.P. Kothari, A.J. Leone, CH.E. Wasley, Performance matched discretionary accrual measures. Journal of Accounting and Economics 39, 163-197 (2005)

18. F. Antonio, Estimating accruals models in Europe: industry-based approaches versus a data-driven approach. Economic Research-Ekonomska Istraživanja 31, 37-54 (2018)

19. S. Chansarn, T. Chansarn, Earnings management and dividend policy of small and medium enterprises in Thailand. International journal of business and society 17, 307328 (2016)

20. J.Z. Giedt, Modelling Receivables and Deferred Revenues to Detect Revenue Management. ABACUS-a Journal of Accounting finance and business studies 54, 181-209 (2018) 